\title{
Arborescences
}

Revue d'études françaises

\section{Présentations des thèses}

Numéro 2, mai 2012

URI : https://id.erudit.org/iderudit/1009275ar

DOI : https://doi.org/10.7202/1009275ar

Aller au sommaire du numéro

Éditeur(s)

Département d'études françaises, Université de Toronto

ISSN

1925-5357 (numérique)

Découvrir la revue

Citer ce document

(2012). Présentations des thèses. Arborescences, (2).

https://doi.org/10.7202/1009275ar

Tous droits réservés @ Département d'études françaises, Université de Toronto, Ce document est protégé par la loi sur le droit d'auteur. L’utilisation des 2012 services d'Érudit (y compris la reproduction) est assujettie à sa politique d'utilisation que vous pouvez consulter en ligne.

https://apropos.erudit.org/fr/usagers/politique-dutilisation/

Cet article est diffusé et préservé par Érudit.

Érudit est un consortium interuniversitaire sans but lucratif composé de l’Université de Montréal, l’Université Laval et l’Université du Québec à

Montréal. Il a pour mission la promotion et la valorisation de la recherche.

https://www.erudit.org/fr/ 


\section{Le Sublime dans les contes et nouvelles de Mérimée, Barbey d'Aurevilly et Villiers de l'Isle-Adam}

\section{Auteur: Maud Pillet}

Thèse menée sous la direction de Roland Le Huenen, soutenue à l'Université de Toronto (Département d'Études françaises) en $20 I I$.

\section{Biographie}

Après avoir soutenu sa thèse en juin 20II, Maud Pillet enseigne actuellement à l'Université de Toronto Scarborough. Elle sintéresse particulièrement à la littérature française du XIX ${ }^{\mathrm{e}}$ siècle, aux genres narratifs et aux questions de poétique, rhétorique et esthétique. Ses recherches actuelles portent sur la poétique et la rhétorique de la folie à travers les figures scientifiques, religieuses et artistiques chez Barbey d'Aurevilly et Villiers de l'Isle-Adam.

\section{Résumé}

Cette thèse sur le sublime dans les contes et nouvelles de Mérimée, Barbey d’Aurevilly et Villiers de l'Isle-Adam a permis de rendre compte du fait que le sublime, tout en se nourrissant d'un héritage à la fois historique, esthétique, philosophique et littéraire et tout en intégrant les enjeux de la modernité, opérait sa métamorphose en participant d'une poétique qui oscille entre l'excès de la représentation et une poétique de la suggestion et de limplicite. En interrogeant les œuvres de ces trois auteurs par rapport aux différentes théories du sublime, en portant une attention particulière à une rhétorique explicite, à une poétique plus suggestive, à un imaginaire implicite ainsi qu’à une théorisation par les auteurs eux-mêmes, nous avons pu dégager les modalités selon lesquelles il agissait en littérature se faisant non seulement l'agent d'une poétique, mais aussi l'écho d’une réflexion sur la création littéraire, l’euvre d'art et sa destination.

En associant les notions "d’acte esthétique " théorisée par Baldine Saint Girons et de sublimation, nous avons montré comment, par l'expérience du sublime, et notamment par le sublime terrifiant la littérature offre une expérience commune au sein de laquelle le lecteur trouve à la fois une forme de jouissance, de création ainsi qu une certaine appartenance culturelle. Par l'effet esthétique propre au sublime, la littérature fonde sa propre morale qui relève de la transmission d’une émotion unique et désintéressée qui reforme un lien entre les hommes en les détachant de l'utilitarisme. Elle redonne accès à une forme de transcendance déniée par la société et grâce à laquelle le lecteur s'ouvre, se dessaisit non pas seulement de l'extérieur, mais du plus profond de lui-même. L'acte esthétique en tant que sublimation se définit alors comme le principe 
même d’une expérience commune qui fait que l'œuvre est modifiée, créée et évolue en même temps qu'elle crée elle-même l'auteur et le lecteur.

Loin de n'être qu’un moment ou un prolongement de la poétique du sublime romantique, la deuxième moitié du XIX ${ }^{\mathrm{e}}$ siècle la dépasse, en ce qu'elle relie le sublime à un mouvement réflexif qui annonce et prépare l'esthétique moderne et sa définition largement essentialiste de l'art. Loin de renvoyer à une faiblesse momentanée du sublime dans une période de crise métaphysique, les nouvelles de Mérimée, Barbey d'Aurevilly et Villiers de l'Isle-Adam témoignent au contraire de la vitalité et de la puissance d'une notion qui se place comme enjeu central de l'art. Relevant d'une poétique qui tout à la fois réinvestit et dépasse la notion de genre et de tradition poétique, le sublime ménage en outre une réflexion qui, tout en limitant la portée représentative du langage, l'ouvre à une présentation de ce qui dépasse le sensible, qu'il s'agisse d'une transcendance ou d'un inconscient. Il est ainsi ce reflet teinté d'une inquiétante étrangeté d'une conscience profondément angoissée, celle de l'auteur d'abord, mais aussi celle du lecteur lui-même renvoyé, par la lumière de l’œuvre, à la part la plus sombre et sans doute la plus créatrice de lui-même.

\section{Mots-clés}

Prosper Mérimée, Jules Barbey d’Aurevilly, Villiers de l’Isle-Adam, sublimation, rhétorique, poétique, esthétique, romantisme terrifiant, religion, tragique, nouvelles. 


\section{Le Réalisme magique dans la littérature contemporaine québécoise}

\section{Auteur: Stéphanie Walsh Matthews}

Thèse menée sous la direction de Janet Paterson et Michel Lord, soutenue à l'Université de Toronto (Département d'Études françaises) en 20 II.

\section{Biographie}

Stéphanie Walsh Matthews est professeur adjointe à l'Université de Ryerson (Department of French and Spanish). Elle est la directrice du programme "Arts and Contemporary Studies".

\section{Résumé}

La présente thèse est une exploration du genre réaliste magique de la littérature contemporaine québécoise. Fondée sur quatre romans exhibant de manière saisissante des aspects du réalisme magique, informée par des ouvrages théoriques ainsi que des analyses de textes réalistes magiques séminaux, et éclairée par la sociocritique québécoise, cette étude vise à élucider le fonctionnement du genre et ses particularités dans la littérature québécoise de 1975 à l'époque actuelle.

Pour mener ce travail, nous analysons: Les Enfants du sabbat d'Anne Hébert, Le Trou dans le mur de Michel Tremblay, L'Ombre de l'épervier de Noël Audet et La Tribu de François Barcelo. Chaque roman a été choisi afin de démontrer les modalités et les spécificités québécoises du genre.

Le réalisme magique étant un terme dont les origines sont problématiques et variées, nous présentons d'abord un historique du genre. À la suite d'une présentation des concepts théoriques, nous identifions les caractéristiques principales du réalisme magique. Notre analyse des Enfants du sabbat met en lumière le rôle des codes antinomiques (le réel et le surnaturel) et quelques thèmes fondamentaux du réalisme magique propre au contexte de production. Nous nous penchons ensuite sur le personnage fantôme, un dispositif réaliste magique qui déclenche un commentaire sur le contexte social dans Le Trou dans le mur. Dans L'Ombre de l'épervier, en plus du personnage-écrivain qui simpose dans la diégèse, tout un réseau de personnages est marqué par l'altérité notamment la figure de la femme et de la sorcière. La Tribu, dont les caractéristiques réalistes magiques sont incontestables, s'avère un roman ludique. Après 
une analyse du jeu onomastique, nous comparons La Tribu au roman de Gabriel García Márquez, Cien años de soledad. Dans un dernier temps, nous démontrons comment les multiples représentations de la femme et de l'oralité traversent l'ensemble du corpus tout en indexant des particularités du réalisme magique dans la littérature contemporaine québécoise.

\section{Mots-clés}

Littérature franco-canadienne, Québec, réalisme magique, Anne Hébert, Michel Tremblay, François Barcelo, Québécois 


\section{Le Discours proverbial chez Ahmadou Kourouma}

\section{Auteur: Claude Zesseu}

Thèse menée sous la direction d'Alexie Tcheuyap, soutenue à l'Université de Toronto (Département d'Études françaises) en 20 II.

\section{Résumé}

Ce travail examine le discours proverbial dans les romans d'Ahmadou Kourouma. Il fait valoir que le discours proverbial de Kourouma traduit la vision cosmologique des personnages romanesques dans cinq domaines, à savoir la religion, la culture matérielle, les animaux, le temps et la femme. Contrairement aux études publiées au cours des quarante dernières années qui traitent de certains de ces domaines sans véritablement privilégier le proverbe comme objet d'analyse, ou qui l'analysent trop rapidement chez Kourouma en utilisant de très minces corpus ou une approche peu efficace et non contextuelle, ce travail déconstruit le proverbe et fait ressortir ses dimensions esthétiques, discursives et idéologiques les plus variées et les plus significatives. La thèse se sert des approches syncrétique, fonctionnelle et intertextuelle pour examiner les proverbes comme discours religieux.

Dans le but d'explorer les proverbes portant sur la culture matérielle, l'étude adopte les concepts du symbolisme, de filiation, de territorialité ainsi que les notions de la hiérarchie des métaux et d'extra-textualité. Le travail aborde les proverbes animaliers en ayant recours aux concepts de métaphore, du symbolisme et du contractualisme. Quant à l'expression temporelle des proverbes, elle est approchée dans une perspective culturelle et spatio-temporelle alors que le rapport du proverbe au genre féminin est déterminé à partir d'une analyse culturelle et sociale de son statut. Cette approche d'une étude multidimensionnelle du proverbe permet ici de déterminer le caractère biculturel, bispirituel, pragmatique, opportuniste et utilitariste de la foi religieuse des personnages kouroumiens. Elle montre en outre que les objets de la culture matérielle sont porteurs de significations sociales, culturelles, littéraires et environnementales. Grâce à son cadre conceptuel élargi et diversifié, ce travail permet également de constater que les animaux possèdent des identités distinctives et remplissent des fonctions romanesque, spirituelle, sanitaire et alimentaire. La thèse met enfin en évidence le caractère pluraliste du temps existentiel, et établit que la condition de la femme est fortement influencée par des facteurs naturels et socioculturels. De ses résultats, l'étude tire la conclusion que le proverbe permet à Kourouma de proposer sa lecture du monde et sa théorie de l'écriture romanesque

\section{Mots-clés}

Littérature africaine, langage, littérature, linguistique, Ahmadou Kourouma, proverbes, Côted'Ivoire 


\section{Transitivité et marquage d'objet différentiel}

\section{Auteur: Rostyslav Bilous}

Thèse menée sous la direction de Yves Roberge, soutenue à l'Université de Toronto (Département d'Études françaises) en 20 II.

\section{Abstract}

This thesis deals with direct object nouns case-marked differentially. According to the commonly assumed generalization nouns marked with ACC case are prototypical objects representing high transitivity, whereas nouns marked with non-accusative cases are not. However, such a view ignores the possibility of a much finer distinction and fails to account for empirical data from languages with rich case morphology, such as Ukrainian. Given the complexity of the phenomenon under study the main objective of our investigation is to account exhaustively for all possible instances of non-accusative case marking and case alternations on direct objects in Ukrainian trying to classify and analyze the data by specifying the factors that condition the distinction 'accusative versus non-accusative case marking' and by integrating the phenomenon of differential object marking (DOM) into a formal model. We present DOM as a phenomenon that, together with the phenomenon of unaccusativity, can be subsumed under a broader concept of non-accusativity (defined as inability of verbs to assign ACC case). In this context we show that in Ukrainian and French morphosyntactic case realization has semantic underpinnings and that issues related to case valuation emanate from the intersection of different phenomena - DOM and nominal incorporation, DOM and verb typology, DOM and the process of (de)transitivization, and so on. However, the (morphosyntactic) visibility of those points of intersection varies from one language to another.

Generativist distinction between syntactic (abstract) and morphological cases as well as the functionalist idea that case markings can be characterized as morphemes having different functional applications constitute the basis of our analysis of data. Using the typological views of these two approaches on the category of case as guidelines in our classification of collected data, we resort to minimalist formalism. Case is treated as an uninterpretable feature and a clear distinction is drawn between two types of case valuation - case checking and case assignment. Structural cases are checked during verbraising and inherent (lexical) cases (among which we find predicate and default cases) are assigned either by a weak (or defective) vor by (an overt or null) preposition (P) in situ. 


\section{Keywords}

Language, literature and linguistics, Transitivity relation, Universal transitivity template, Direct object marking, Ukrainian language, Rich case morphology, Nonaccusative case marking, Case alternations, Semantic feature realization, Ukrainian

\section{Résumé}

Cette thèse traite des noms objets directs marqués d'un cas différentiel. Selon une généralisation communément acceptée les noms marqués avec le cas ACC sont des objets prototypiques représentant la haute transitivité, tandis que les noms objets au cas différentiel ne le sont pas. Une telle vision ignore cependant la possibilité d’une distinction beaucoup plus fine et ne rend pas compte des données empiriques des langues à morphologie casuelle riche, telles que lukurainien. Étant donnée la complexité du phénomène à létude, l'objectif principal de notre investigation est de rendre compte de façon exhaustive de toutes les instances du marquage non-accusatif et des alternances casuelles sur les noms objets directs en ukrainien, de classifier et d'analyser les données en spécifiant les facteurs qui conditionnent la distinction 'marquage accusatif versus marquage non-accusatif ainsi qu'en intégrant le marquage d'objet différentiel (MOD) dans un modèle formel. Nous présentons le MOD comme un phénomène qui, avec le phénomène d’inaccusativité, peut être subsumé sous un concept plus large de nonaccusativité (défini comme incapacité de verbes d'assigner le cas ACC). Dans ce contexte nous démontrons que la réalisation morphosyntaxique de cas en ukrainien et en français à des fondements sémantiques et que les problèmes reliés à la validation de cas proviennent du croisement de phénomènes différents - du MOD et de lincorporation nominale, du MOD et de la typologie verbale, du MOD et du processus de (dé)transitivisation, et ainsi de suite. Cependant, la visibilité (morphosyntaxique) de ces points de croisement varie d'une langue à l'autre.

La distinction générative entre les cas syntaxiques (abstraits) et les cas morphologiques ainsi que lidée fonctionnaliste de multifonctionnalité de cas constitue la base de notre analyse de données ramassées. À partir de ces deux approches on analyse les données en faisant recours au formalisme minimaliste. On traite le cas comme un trait ininterprétable et on fait une distinction claire entre deux types de validation casuelle vérification et assignation. Les cas structurels sont vérifiés lors de la montée verbale et les cas inhérents (lexicaux) (parmi lesquels on trouve les cas de prédicat et de défaut) sont assignés soit par le faible (ou défectif) $v$, soit par une préposition $\mathrm{P}$ (manifeste ou nulle) in situ.

\section{Mots-clés}

Langage, linguistique, relation transitivité, marquage non-accusatif, marquage d'objet différentiel, morphologie casuelle riche, réalisation morphosyntaxique de cas, ukrainien 


\title{
Sociolinguistic (re)constructions of diaspora portugueseness Portuguese-Canadian youth in Toronto
}

\author{
Auteur: Emanuel A. da Silva
}

Thèse menée sous la direction d'Anne-Marie Brousseau, soutenue à l'Université de Toronto (Département d'Études françaises) en $20 I$ I.

\section{Biographie}

Dr. da Silva est actuellement chercheur au Centre de recherches en éducation francoontarienne (CREFO) à l'Université de Toronto. Ses domaines de recherche principaux sont la sociolinguistique et la linguistique anthropologique. Il sinntéresse à l'étude critique et ethnographique des idéologies langagières, des marchés multilingues et multiculturelles, de la structuration sociale, des identités ethnolinguistiques et du post-nationalisme. Parmi ses publications, on note «Heroes or zeros? Portuguese-Canadian youth and the cost of mobilizing different sociolinguistic resources " dans la revue International Journal of Multilingualism (à paraitre en 20I2), «From protector to producer: the role of the State in the discursive shift from minority rights to economic development » avec M. Heller dans la revue Language Policy (2009), et «Bilingualism and the globalized new economy: The commodification of language and identity ", avec M. McLaughlin \& M. Richards dans Bilingualism: A Social Approach (dir. M. Heller, 2007).

\section{Abstract}

This dissertation demonstrates that notions of language and identity are not entirely about personal characteristics (what a person is born with, what is "in his blood"), nor are they entirely about agency (how a person chooses to present herself). Instead, they are largely about markets and about the multiple positionings of social actors within markets that are structured by ideologies of the nation state, immigration and the globalized new economy. This critical perspective challenges the normalized view that immigrant (diasporic) communities are simply natural social groupings or depoliticized transplantations of distinct ethnolinguistic units from their "homeland". They are, like language and identity, carefully constructed and managed social projects that are shaped by forces from within and from without.

In Canada, the conditions for the institutionalization and (re)production of ethnolinguistic differences, which also make and mark class relations, are strengthened by the state's multiculturalist policy. The Portuguese-Canadian community is one such ethnolinguistic 
market and the goal of this research is to examine which forms of portugueseness dominate the market, why and with what consequences for whom. Building from an ethnographic and critical sociolinguistic approach (Bourdieu 1977, Heller 2002), the qualitative data behind this research was produced through a two-year ethnography, participant observations and semi-structured interviews drawing primarily from six second-generation Portuguese-Canadians and members of their social networks.

The findings suggest that the kind of portugueseness that dominates the PortugueseCanadian market is one from Mainland Portugal; one that is folklorized, patriarchal, and that promotes (Mainland) Portuguese monolingualism and false cultural homogeneity. A consequence of this sociolinguistic structuration is a division between Azoreans and Mainlanders who make up two parts of the same Portuguese market; partners in conflict over the legitimacy and value of their linguistic and social capital. Furthermore, the inheritors of this market, the second and subsequent generations, navigate discursive spaces filled with contradictions that often marginalize them. Their experiences highlight strategic mobilizations of Portuguese language and identity, as well as the consequences of having delegitimized cultural and linguistic capital. In short, this dissertation highlights the productive tensions between structure and agency, between uniformity and variability, and between exclusion and inclusion.

\section{Keywords}

Social sciences, Language, literature and linguistics, Sociolinguistics, Ethnography, Linguistic anthropology, Identity, Multiculturalism, Globalization, Postnationalism, Portuguese-Canadian, Toronto, Ontario 